УДК 316.613.434-053.4

DOI https://doi.org/10.26661/2310-4368/2021-2-13

\title{
ОСОБЛИВОСТІ ПРОЯВУ АГРЕСИВНОСТІ У ДІТЕЙ СТАРШОГО ДОШКІЛЬНОГО ВІКУ
}

\author{
Шевченко Н. Ф. \\ доктор психологічних наук, професор, \\ професор кафедри психологіі \\ Запорізький національний університет \\ вул. Жуковського, 66, Запоріжжя, Україна \\ orcid.org/0000-0002-5297-6588 \\ shevchenkonf.20@gmail.com
}

Булгакова О. Ю.

доктор психологічних наук, дочент,

декан факультету дошкільної педагогіки та психології,

Державний заклад «Південноукраӥнський начіональний педагогічний університет

імені К.Д. Уиинського»

вул. Старопортофранківська, 26, Одеса, 65000

orcid.org/0000-0002-1750-0349

halen30@ukr.net

Ціник Я. Л.

магістрант кафедри психології

Запорізький національний університет

вул. Жуковського, 66, Запоріжжя, Україна

orcid.org/0000-0002-2392-5693

yeriskovskaya.yana@gmail.com

Ключові слова: агресивність, агресія, тривожність, стариий дошкільний вік, психологічна корекція агресивності.
В статті представлено результати емпіричного дослідження проявів агресивності у дітей старшого дошкільного віку. Агресивність дитини дошкільного віку охарактеризовано як специфічну форму іiі дій, завдяки яким дитина демонструє переваги у силі або використовує силу стосовно інших. Визначено домінуючі чинники формування агресивної поведінки дітей дошкільного віку: стилі сімейного виховання та системи сімейних взаємин, чинники мікросередовища (приклади агресивної поведінки, що демонструютьдорослі, одноліткитателебачення), фізичніумовиоточуючого середовища; вікові та індивідуально-психологічні особливості особистості. Вивчення прояву агресивності у дітей дошкільного віку за шкалою агресивності виявило перевагу вербальної агресії над іншими видами; меншою мірою представлена фізична та непряма агресія. Встановлено, що більшість досліджуваних дошкільників не проявляють агресивність або лише мають тенденції до агресивної поведінки. Результати дослідження за методикою «Неіснуюча тварина» показали, що більша частина вибірки виявляють слабкий рівень агресивності або зовсім не проявляють піi. Найменшу частку складають дошкільники 3 високим та дуже високим рівнем агресивності. Вивчення прояву агресивності за методикою «Тест Руки» засвідчило, що в більшості досліджуваних дошкільників відсутні відкриті агресивні дії. Водночас, у третини вибірки зафіксовано показники 
вище за норму, що вказує на тенденцію до відкритої агресивної поведінки, небажання пристосовуватися до своєрідного соціального оточення. Аналіз результатів за методикою «Тест тривожності» показав, що значна частка дошкільників мають середній та високий рівні тривожності. Тривожність дитини може виступати особистісним параметром, який сприяє прояву агресивності. На основі теоретичних підходів до проблеми дитячої агресивності в сучасній зарубіжній та вітчизняній психології, вікових особливостей старшого дошкільного віку, а також результатів проведеного емпіричного дослідження, було визначено основні напрями роботи та завдання психокорекційного тренінгу зі зниження та попередження прояву агресивності у дітей старшого дошкільного віку.

\title{
FEATURES OF THE AGGRESSIVENESS MANIFESTATION IN CHILDREN OF SENIOR PRESCHOOL AGE
}

\author{
Shevchenko N. F. \\ Doctor of Psychological Sciences, Professor, \\ Professor at the Chair of Psychology \\ Zaporizhzhia National University \\ Zhukovskoho str., 66, Zaporizhzhia, Ukraine \\ orcid.org/0000-0002-5297-6588 \\ shevchenkonf.20@gmail.com \\ Bulgakova O. Yu. \\ Doctor of Psychology, Associate Professor, \\ Dean of the Faculty of Preschool Pedagogy and Psychology \\ South Ukrainian National Pedagogical University named after K. D. Ushynsky \\ Staroportofrankovskaya str., 26, Odesa, Ukraine \\ orcid.org/0000-0002-1750-0349 \\ halen30@ukr.net \\ Tsinyk Ya. L. \\ Undergraduate at the Department of Psychology \\ Zaporizhzhia National University \\ Zhukovskoho str., 66, Zaporizhzhia, Ukraine \\ orcid.org/0000-0002-2392-5693 \\ yeriskovskaya.yana@gmail.com
}

Key words: aggressiveness, aggression, anxiety, senior preschool age, psychological correction of aggression.
The article presents results of an empirical study of features of aggression manifestations in children of senior preschool age. The aggression of a preschool child has been characterized as a specific form of his or her actions, by which the child demonstrates advantages in strength or uses force over others. The dominant factors of formation of the aggressive behavior of preschool children have been determined: styles of family upbringing and system of family relations, microenvironmental factors (examples of an aggressive behavior demonstrated by adults, peers and television), physical conditions of the environment; age and individual psychological characteristics of an individual. Study of the aggression manifestation in preschool children by the scale of aggression has revealed the advantage of the verbal aggression over other types; physical and indirect aggression 
are less represented. It has been found that most of the studied preschoolers do not show aggression or only have a tendency to the aggressive behavior. The results of the study by the method of "Non-existent animal" has shown that most of the sample demonstrate a low level of aggression or do not demonstrate it at all. The smallest part of preschoolers has a high and very high level of aggression. The study of the aggression manifestation by the method of "Hand-Test" has shown that in most of the studied preschoolers there are no overt aggressive actions. However, in the third of the sample there have been diagnosed indicators above the norm, which mean a tendency to overt aggressive behavior, unwillingness to adapt to the social environment. Analysis of results by the "Anxiety Test" has shown that a significant part of preschoolers has medium and high levels of anxiety. A child's anxiety can be a personal parameter that contributes to the manifestation of aggression. Theoretical approaches to the problem of a child aggression in modern foreign and domestic psychology, age characteristics of the older preschool age, as well as the results of an empirical research, have allowed to indicate the main directions and objectives of the psychological correction program to reduce and prevent aggression in senior preschool age children.

Вступ. Актуальність дослідження визначається соціальними та економічними реконструкціями, які призводять не тільки до демократизації суспільства, але й до посилення проблем, пов'язаних зі зростанням насильства, конфліктності і напруженості між людьми. Перевантаженість негативними емоціями закономірно веде до появи ворожості, конфліктів, агресії, зокрема, у сімейних взаєминах. Проблема агресії в дитячому віці $\epsilon$ особливо актуальною за сучасних умов, оскільки зачіпає не тільки навколишніх людей - батьків, вихователів, однолітків, але й створює труднощі для самої дитини у їі взаєминах 3 оточуючими. Окрім цього, агресивність у дитячому віці впливає не тільки на взаємини 3 оточуючими, але й визначає загальний розвиток особистості дитини. Особливо гостро ця проблема проявляється в старшому дошкільному віці - у зв'язку з переходом дитини з дитячого садку до школи, тобто зміною соціальної ситуації розвитку. Неконтрольована поведінка в більш ранньому дитячому віці може перерости в поведінку з асоціальними тенденціями в підлітковому віці $[5 ; 16]$. Таким чином, своєчасне виявлення дітей, які проявляють агресивність в поведінці, необхідно 3 метою попередження несприятливого варіанта розвитку і для організації необхідної психологічної допомоги.

В західній психології агресивна поведінка людини розглядається в рамках інстинктивістського, біологічного, соціального та когнітивного підходів [1; 3; 9; 14], які подають різні трактування агресивності та агресивної поведінки.

У сучасній психологічній науці проблема агресії висвітлена в працях вітчизняних [4; 12] та зарубіжних вчених $[6 ; 11 ; 13 ; 15]$. Науковцями досліджено прояви агресивності та агресивної поведінки на різних етапах онтогенезу, переважно, в осіб молодшого шкільного, підліткового та юнацького віку $[17 ; 18]$. Водночас аналіз наукової літератури засвідчив дефіцит праць, в яких би висвітлювалася проблема проявів агресивності в дошкільному віці $[6 ; 10 ; 16 ; 20]$, зокрема, в старшому дошкільному віці.

Мета статті: представити результати емпіричного дослідження проявів агресивності у дітей старшого дошкільного віку.

Виклад основного матеріалу дослідження 3 обгрунтуванням отриманих наукових результатів. Визначення терміну агресії з позицій різних наукових підходів має широкий діапазон пояснення. Зазвичай його використовують для позначення таких дій, які можуть бути мотивовані: страхом або фрустрацією; бажанням викликати страх у інших; прагненням досягнути визнання власних ідей чи здійснення власних інтересів [5; 20]. Аналіз наукової літератури 3 проблеми агресії та агресивності (як психологічної властивості особистості) засвідчив існування трьох основних наукових концепцій, що трактують природу агресивності: інстинктивістська (агресія як вроджений інстинкт індивіда; теорії психоаналітичного спрямування), теорія фрустрації (агресія як поведінкова реакція на фрустрацію) та соціального научіння (агресія як засвоєння поведінки в процесі соціалізації через спостереження певного способу дій) $[3 ; 9 ; 12]$.

На думку провідних фахівців $[2 ; 4 ; 6 ; 8]$, прояви агресії - одна 3 доволі поширених у дошкільному віці проблем, оскільки ті чи інші форми агресивності притаманні більшості 5-7-річних дітей. За даними досліджень цих науковців, із засвоєнням основних моральних правил і норм поведінки у багатьох старших дошкільників прояви агресив- 
ності поступаються просоціальним формам. Водночас, в деяких дітей означеної вікової категорії агресія як стійка форма поведінки не лише зберігається, а й розвивається, трансформуючись у стійку негативну якість особистості, наслідком чого $\epsilon$ деформація особистісного розвитку, звуження можливостей повноцінного спілкування з однолітками.

В загальному вигляді агресивність дошкільника характеризується як специфічна форму його дій, завдяки яким він демонструє переваги у силі або використовує силу стосовно інших, прагне нанести шкоди. Проте не кожен прояв агресивної поведінки дитини слід однозначно оцінювати як негативний. Виникаючи в критичній ситуації, агресія виконує захисну функцію, допомагає дитині мобілізуватися для розв'язання проблеми [7].

Формування агресивності у дитячому віці обумовлене багатьма внутрішніми та зовнішніми чинниками. Враховуючи соціальну ситуацію розвитку старшого дошкільного віку, а також беручи до уваги дані провідних досліджень дитячої агресивності, можна визначити такі домінуючі чинники формування агресивної поведінки дітей дошкільного віку: стилі сімейного виховання та системи сімейних взаємин, чинники мікросередовища (приклади агресивної поведінки, що демонструють дорослі, однолітки та телебачення), фізичні умови оточуючого середовища; вікові та індивідуально-психологічні особливості особистості [2; 7].

Дослідницьку вибірку склали 63 дитини старшого дошкільного віку (5-6 років). Дослідження проводилось на базі закладів дошкільної освіти № 89 і № 172 м. Запоріжжя.

Психодіагностичний інструментарій дослідження склали методики: «Малюнок неіснуючої тварини» [15] для виявлення наявності агресії у дітей; «Шкала агресивності» (авт. П. Орпінас, Р. Франковскі [19]) з метою визначення рівня агресії дошкільників за допомогою експертних оцінок; «Тест руки» (авт. Е. Вагнер, Б. Брайклін [10]) для діагностики агресії; «Тест тривожності» (авт. Р. Темпл, В. Амен, М. Дорки [15]) з метою вивчення ступеню тривожності дошкільників.

Перейдемо до аналізу результатів емпіричного дослідження. Розглянемо дані, отримані за методикою «Шкала агресивності» [19]. Методика вимірює поведінку дітей, яка може призвести до психологічної чи фізичної травматизації інших та дозволяє отримати інформацію про частоту прояву прямих форм фізичної й вербальної агресії та гніву. В ході дослідження експерти-вихователі давали інформацію про поведінку дітей протягом останніх семи днів.

Згідно 3 отриманими даними, експерти відмітили у досліджуваних дітей прояви агресії. Зокрема, вихователі відзначили перевагу вербальної агресії (виявлено у $36,51 \%$ респондентів) над іншими видами. Прояви фізичної агресії зафіксовано у $34,92 \%$ дітей, а непрямої - в 17,46\% досліджуваних.

Слід відзначити, що більшість досліджуваних дошкільників, за даними експертів, не проявляють агресивність або лише мають тенденції до агресивної поведінки (фізична агресія - 65,08\%; вербальна агресія - 63,49\%; непряма агресія $82,54 \%)$.

Перейдемо до результатів дослідження за методикою «Неіснуюча тварина». Кількісний аналіз даних та інтерпретації (контент-аналіз) малюнків ми здійснювали за I.A. Фурмановим [15], яким виокремлено 15 «симптомокомплексів» агресії. Особлива увага в симптомокомплексі «Агресія» приділена кількості, розташуванню і характеру кутів у малюнку, прямим символам агресії (кігті, зуби, дзьоби, роги, копита, всілякі шипи, велика кількість рук або ніг), характеру ліній (лінії прямі, гостро намальовані кути, чи використовується в малюнку штрихування). Нами також зверталася увага на випадки вмонтування механічних частин в тіло «тварини»: постановка тварини на постамент, тракторні або танкові гусениці, триніжок; прикріплення до голови пропелера, гвинта; вмонтування в око електролампи, в тіло і кінцівки тварини - рукояток, клавіш і антен. В процесі аналізу малюнків нам зустрічалася фігура кола, що символізує і виражає тенденцію до скритності, замкнутість, закритість свого внутрішнього світу, небажання давати відомості про себе оточуючим, тривожність.

Згідно з отриманими даними, 49,21\% дітей, тобто більша частина вибірки, виявили слабкий рівень агресивності або ії відсутність. В 38,1\% досліджуваних зафіксовано середній рівень агресивності. Найменшу частку склали дошкільники 3 високим (9,52\%) та дуже високим $(3,17 \%)$ рівнями агресивності.

Розглянемо результати за методикою «Тест Руки» (Е. Вагнер, Б. Брайклін [10]). На думку авторів, відповіді за категоріями 1 (агресія) та 2 (вказівка) свідчать про готовність досліджуваного до зовнішнього прояву агресивності, небажання пристосовуватись до оточення. Категорії відповідей 3 (страх), 4 (прив'язаність), 5 (комунікація), 6 (залежність) вказують на тенденцію до дій, спрямованих на пристосування до соціального середовища та незначну ймовірність агресивної поведінки. В нашому дослідженні ми використовували інтерпретацію результатів тесту, яка грунтується на порівнянні сумарного балу з тестовими нормами і прийнятті рішення про рівень агресивності і актуальному стані досліджуваного. В ході дослідження ми відносили відповіді досліджуваних дошкільників до певних категорій:

1. Агресія: рука сприймається як домінуюча, завдає пошкодження, активно захоплююча 
який-небудь предмет, що здійснює агресивну дія (щипає, давить комаха, готова нанести удар тощо).

2. Вказівка: рука бере участь у дії імперативного характеру: веде, направляє, перешкоджає, панує над іншими людьми (дає вказівку, каже «вийди геть» тощо).

3. Страх: рука виступає у відповідях як жертва агресивних проявів іншої особи або прагне захистити кого-небудь від фізичних впливів; може сприйматися як завдає пошкодження самої себе. До цієї категорії також включалися відповіді, що містили тенденції до заперечення агресії (не зла рука; кулак стиснутий, але не для удару; піднята в страху рука, рука, відвертає удар тощо).

4. Емоційність: рука висловлює любов, позитивні емоційні настанови до інших людей; бере участь у дії, виражає прихильність, позитивне ставлення, доброзичливість (дружнє рукостискання; поплескування по плечу; рука, яка гладить тварину, яка дарує квіти тощо).

5. Комунікація: рука бере участь в комунікативній дії - звертається до кого-небудь, контактує або прагне встановити контакти (жестикуляція в розмові, мова жестів, показує дорогу тощо).

6. Залежність: рука висловлює підпорядкування іншим особам: бере участь в комунікативній дії в позиції «знизу», успіх якої залежить від доброзичливого ставлення іншої сторони (прохання; піднята рука для питання; рука, протягнута за милостинею; людина зупиняє попутну машину тощо).

7. Демонстративність: рука різними способами виставляє себе на показ, бере участь в демонстративній дії (показує кільце, милується манікюром, показує тіні на стіні, танцює, грає на музичному інструменті тощо).

8. Каліцтво: рука пошкоджена, деформована, хвора, нездатна до будь-яких дій (поранена рука, рука хворого, зламаний палець тощо).

9. Активна безособовість: рука бере участь у дії, не пов'язаній з комунікацією; проте рука повинна змінити своє фізичне місце розташування, докласти зусилля (втягає нитку в голку, пише, шиє, веде машину, пливе тощо).

10. Пасивна безособовість: рука в спокої, або спостерігається поява тенденції до дії, завершення якої не вимагає присутності іншої людини, але при цьому рука все ж не змінює свого фізичного стану (лежить, відпочиваючи; спокійно витягнута; звісилась під час сну тощо).

11. Опис: у цю категорію входять описи руки без вказівки на чинені нею дії (пухка рука, красива рука, рука дитини тощо).

Згідно 3 отриманими даними, в $69,84 \%$ дошкільників відсутні відкриті агресивні дії (показники в межах або нижче норми - K>1). В 30,16\% респондентів зафіксовано показники вище норми - К $<1$. Саме відповіді перших двох категорій (агресія та вказівка) підвищують ймовірність прояви агресії у відкритій поведінці. Ïх об'єднує відсутність прагнення «зважати» на інших людей, враховувати почуття, права і наміри інших в своїй поведінці. Тенденції до дії в цих категоріях відображають готовність до відкритої агресивної поведінки, небажання пристосовуватися до своєрідного соціального оточення.

Перейдемо до аналізу результатів за методикою «Тест тривожності» (Р. Темпл, В. Амен, М. Дорки) [15]. Тривожність розглядається як вид емоційного стану, функція якого - в забезпеченні безпеки суб' єкта на особистісному рівні. Тривожність, яку відчуває дитина стосовно певної ситуації залежить від власного негативного емоційного досвіду в цій або подібних ситуаціях. Завищений рівень тривожності свідчить про недостатню емоційну пристосованість дитини до тих або інших соціальних ситуацій. Експериментальне виявлення ступеню тривожності розкриває внутрішнє ставлення дитини до певної ситуації, дає інформацію про характер взаємин дитини 3 однолітками та дорослими в сім’'і, дитячому садку. В ході дослідження ми розрахували індекси тривожності досліджуваних дошкільників.

Дані діагностики показали, що значна частка дошкільників мають середній $(44,44 \%)$ та високий (36,51\%) рівні тривожності. Лише в 19,04\% досліджуваних індекс тривожності знаходиться в межах низького рівня. Тривожність дитини може виступати особистісним параметром, який сприяе прояву агресивності. Головним джерелом тривоги в дошкільному віці $є$ сім'я, оскільки саме тип сімейного виховання $\epsilon$ визначальним фактором впливу на психіку дитини. Надалі, роль сім’ї значно зменшується, оскільки зростає роль школи та однолітків. Висока ймовірність виховання тривожної дитини в ситуації сімейного виховання по типу гіперопіки та авторитарного характеру спілкування (надмірна турбота, контроль, наявність обмежень i заборон, завищені вимоги з боку батьків і вихователів, часті докори). При такому вихованні дитина втрачає впевненість в собі, постійно боїться негативної оцінки, що може перерости в тривожність як стабільне особистісне утворення [8; 16].

Розглянемо питання щодо профілактики та корекції агресивності в старшому дошкільному віці.

3 точки зору сучасних дослідників [2; 5-7], найбільш ефективною формою профілактичної та корекційної роботи агресивної поведінки дітей старшого дошкільного віку є соціально-психологічний тренінг. Забезпечення дієвості та ефективності тренінгових заходів, спрямованих на зниження агресивності та агресії у дошкільників, відбувається за рахунок включення в них наступних компонентів [10]: 
1. Афективний - на основі встановленої залежності між агресією та негативно забарвленими емоційними переживаннями, розвивальні заходи мають бути спрямовані на зниження афективно-агресивного сприйняття оточуючої дійсності шляхом особистісного прийняття і засвоєння соціально-прийнятних конструктивних способів розрядки афективно-агресивного потенціалу.

2. Когнітивний - тренінг має спрямовуватися на вироблення у дошкільників умінь оптимального спілкування, зокрема: розуміння когнітивних передумов виникнення різних психологічних станів; уміння визначати власну роль у виникненні непорозумінь з іншими; здатність сприймати оточуючих та себе такими як $\epsilon$.

3. Поведінковий - розвивальні заходи мають спрямовуватися на формування у дітей навичок гнучкості поведінки, здатності на основі засвоєних афективних та когнітивних умінь і навичок оцінювати комунікативні ситуації спілкування, прогнозувати їх розвиток та керувати їх перебігом.

Враховуючи вікові особливості старшого дошкільного віку, основною формою реалізації тренінгових завдань має бути гра. Саме гра, як провідна діяльність цього вікового періоду, сприяє усвідомленню дитиною соціально прийнятних форм поведінки; у грі ці форми стають ï власними, а не нав'язливими зовні утвердженнями [7; 17]. Корекція поведінки проблемних дітей повинна йти за рахунок спонукання активності дитини через пошук і розкриття життєвих смислів, розвиток творчості та допитливості. Це веде до створення відповідних переживань, формування позитивного емоційного ставлення до дійсності. Слід зауважити, що в старшому дошкільному віці гра, попри все інше, повинна виконувати ще й навчальну функцію [3; 20].

Серед основних завдань психокорекційної роботи 3 метою зниження та попередження прояву агресивності у дітей старшого дошкільного віку, можна виділити наступні:

- навчання дошкільників конструктивним формам поведінки та формування у них комунікативних навичок;

- сприяння покращенню взаємовідносин дошкільників з оточуючими завдяки формування навичок самоконтролю та саморегуляції;

- розвиток здатності адекватного сприйняття себе та інших; розвиток здатності розуміти емоційний стан іншого;

- зниження надмірного напруження та тривоги за рахунок розширення спектру емоційного реагування;

- ігрова профілактика агресивної поведінки;

- сприяння розвитку адекватних моральних уявлень.
Розглянемо засоби впливу, які можуть використовуватись при розробці психокорекційної програми $[2 ; 3 ; 5 ; 8 ; 10]$. Для відреагування негативних емоцій, зняття емоційного напруження доцільно застосовувати рухливі ігри, фізичні вправи, техніки ауторелаксації та саморегуляції. Розглядаючи агресивну поведінку в якості певного типу реагування на зовнішні стимули, об'єктом впливу стає поведінка дошкільників, а основною метою - навчання досліджуваних конструктивним формам поведінки - альтернативних до агресивної. Для цього мають відпрацьовуватись моделі прийнятної поведінкової активності та емоційного реагування за допомогою таких методів роботи дітьми, як бесіда, тренінгові вправи (в тому числі фізичні вправи, рухливі ігри, психогімнастичні вправи), арт-терапія (малювання, етюди, пантоміма), рольове програвання моделей бажаної поведінки у різних життєвих ситуаціях, техніки ауторелаксації.

Висновки 3 даного дослідження і перспективи подальших розробок у даному напрямку. В статті представлено результати емпіричного дослідження проявів агресивності у дітей старшого дошкільного віку. Вивчення прояву агресивності у дітей дошкільного віку за шкалою агресивності виявило перевагу вербальної агресії над іншими видами; в меншому ступені представлена фізична та непряма агресія. Більшість досліджуваних дошкільників не проявляють агресивність або лише мають тенденції до агресивної поведінки. Результати дослідження за методикою «Неіснуюча тварина» показали, що більша частина вибірки виявляють слабкий рівень агресивності або зовсім не проявляють iii. Найменшу частку складають дошкільники 3 високим та дуже високим рівнем агресивності. Вивчення прояву агресивності за методикою «Тест Руки» засвідчило, що в більшості досліджуваних дошкільників відсутні відкриті агресивні дії. В чверті вибірки зафіксовано показники вище норми. Аналіз результатів за методикою «Тест тривожності» показав, що значна частка дошкільників мають середній та високий рівні тривожності. На основі теоретичних підходів до проблеми дитячої агресивності в сучасній зарубіжній та вітчизняній психології, вікових особливостей старшого дошкільного віку, а також результатів проведеного емпіричного дослідження, було визначено основні напрямки роботи та завдання психокорекційного тренінгу зі зниження та попередження прояву агресивності у дітей старшого дошкільного віку.

Перспективним напрямком розвитку наукової проблематики вважаємо розробку, впровадження та перевірку ефективності програми 3 корекції та профілактики агресивної поведінки дітей дошкільного віку. 


\section{ЛІТЕРАТУРА}

1. Бандура А., Уолтерс Р. Подростковая агрессия. М. : Апрель-пресс, 2000. 507 с.

2. Барченкова Н.И., Арсёнова М.А., Суворова Н.Н. К проблеме профилактики агрессивного поведения детей старшего дошкольного возраста. Концепт: научно-методический электронный журнал. 2013. T. 3. C. 2671-2675. URL: http://e-koncept.ru/2013/53537.htm

3. Берковиц Л. Агрессия: причины, последствия и контроль. СПб. : Прайм - ЕВРОЗНАК, 2002. 512 с.

4. Бовть О. Б. Агресивні реакції та шляхи їх корекції в молодших школярів : автореф. дис. ... канд. психол. наук : 19.07.00. К., 2001. 18 с.

5. Емоційний розвиток дитини (Збірник психол. тестів, програми тренінгу емоційної зрілості, тренув. вправи для дітей дошк., мол. шкіл. та підл. віку / упоряд. С. Максименко та ін.). К. : СПДФО О.П. Главняк : Мікрос. - СВС, 2004. 111 с.

6. Истратова О. Н. Диагностика и коррекция агрессивного поведения у детей дошкольного возраста : Дис. ... канд. психол. наук : 19.00.07 : Таганрог, 1998. 182 с.

7. Кононко О. Дитяча агресія: специфіка, причини виникнення, виховання вміння ії долати. Нова педагогічна думка. 2019. № 3. С. 80-85.

8. Корытченкова Н.И. Влияние стилей семейных отношений на агрессивность личности ребенка : Дис. ... канд. психол. наук : 19.00.01 : Новосибирск, 2000. 197 с.

9. Лоренц К. Агрессия (так называемое зло). M. : Litres, 2020.

10. Мицкан Т. С. Агресивна поведінка дітей дошкільного віку: причини виникнення та профілактика : автореф. дис. ... канд. психол. наук : 19.00.07 ; Острог, 2013. 20 с.

11. Налчаджян А. Агрессивность человека. СПб. : Питер, 2007. 736 с.

12. Павелків В. Р. Проблеми агресії в зарубіжній літературі. Актуальні проблеми психології : зб. наукових праць Інституту психології ім. Г. С. Костюка АПН України. К. : Міленіум, 2004. Вип. 12. C. $115-118$.

13. Румянцева Т.Г. Факторы, способствующие агрессии. Психология человеческой агрессивности / Под ред А.Е. Тарас. Минск : Карвест, 1999. С. 64-115.

14. Фрейд 3. Я и Оно. М. : Эксмо, 2019. 160 с.

15. Фурманов И. А. Агрессия и насилие : диагностика, профилактика и коррекция. СПб. : Речь, 2007. 480 с.

16. Шевченко Н. Ф., Ціник Я. Емпіричне дослідження проявів агресивності у дітей старшого дошкільного віку. The XIII International Science Conference «Development of modern science: theory, methodology, practice», March 18-19, 2021, Madrid, Spain. 221 p. Madrid: International Science Group, 2021. C. 201-204.

17. Cabello, R., Gutiérrez-Cobo, M. J., \& Fernández-Berrocal, P. (2017). Parental Education and Aggressive Behavior in Children: A Moderated-Mediation Model for Inhibitory Control and Gender. Frontiers in psychology, 8, 1181. https://doi.org/10.3389/fpsyg.2017.01181

18. Mitrofan, O., Paul, M., Weich, S. et al. Aggression in children with behavioural/emotional difficulties: seeing aggression on television and video games. BMC Psychiatry 14, 287 (2014). https://doi.org/10.1186/ s12888-014-0287-7

19. Orpinas P., Frankovski R. The Aggression Scale : A Self-Report Measure of Aggressive Behavior for Young Adolescents. Journal of Rarly Adolescents. 2001. Vol. 21. N. 1. P. 50-67.

20. Suurland, J., van der Heijden, K. B., Huijbregts, S. C. J., Smaling, H. J. A., de Sonneville, L. M. J., Van Goozen, S. H. M., et al. (2016). Parental perceptions of aggressive behavior in preschoolers: inhibitory control moderates the association with negative emotionality. Child Dev. 87, 256-269. doi: 10.1111/ cdev. 12455

\section{REFERENCES}

1. Bandura, A. \& Uolters, R. (2000). Podrostkovaya agressiya [Teenage aggression]. Moscow : Aprel'-press. [in Russian].

2. Barchenkova, N.I., Arsonova, M.A. \& Suvorova, N.N. (2013). K probleme profilaktiki agressivnogo povedeniya detey starshego doshkol'nogo vozrasta [On the Problem of Prevention of Aggressive Behavior in Older Preschool Children]. Kontsept: nauchno-metodicheskiy elektronnyy zhurnal-Concept: scientific and methodological electronic journal. 3: 2671-2675. URL: http://e-koncept.ru/2013/53537.htm [in Russian].

3. Berkovits, L. (2002). Agressiya: prichiny, posledstviya i kontrol' [Aggression: causes, consequences and control]. St. Petersburg : Praym - YEVROZNAK. [in Russian].

4. Bovt', O. B. (2001). Ahresyvni reaktsiyi ta shlyakhy yikh korektsiyi v molodshykh shkolyariv [Aggressive reactions and ways of their correction in junior high school students]. Candidate's thesis abstract. Kyiv. [in Ukrainian]. 
5. Maksymenko, S.D. et al. (2004). Emotsiynyy rozvytok dytyny (Zbirnyk psykhol. testiv, prohramy treninhu emotsiynoyi zrilosti, trenuv. vpravy dlya ditey doshk., mol. shkil. ta pidl. viku [Emotional development of a child (Collection of psychological tests, training programs for emotional maturity, training exercises for children of preschool, junior school and teenage]. Kyiv : SPDFO O.P. Hlavnyak : Mikros. - SVS. [in Ukrainian].

6. Istratova, O. N. (1998). Diagnostika i korrektsiya agressivnogo povedeniya u detey doshkol'nogo vozrasta [Diagnostics and correction of aggressive behavior in preschool children] : Candidate's thesis.Taganrog. [in Russian].

7. Kononko, O. (2019). Dytyacha ahresiya: spetsyfika, prychyny vynyknennya, vykhovannya vminnya yiyi dolaty [Children's aggression: specifics, causes, education, the ability to overcome it]. Nova pedahohichna dumka - New pedagogical thought. 3: 80-85. [in Ukrainian].

8. Korytchenkova, N.I. (2000). Vliyaniye stiley semeynykh otnosheniy na agressivnost' lichnosti rebenka [Influence of the styles of family relationships on the aggressiveness of the child's personality] : Candidate's thesis. Novosibirsk. [in Russian].

9. Lorents, K. (2020). Agressiya (tak nazyvayemoye zlo) [Aggression (the so-called evil)]. Moscow : Litres, 2020. [in Russian].

10. Mytskan, T. S. (2013). Ahresyvna povedinka ditey doshkil'noho viku: prychyny vynyknennya ta profilaktyka [Aggressive behavior of preschool children: causes and prevention] : Candidate's thesis abstract. Ostroh. [in Ukrainian].

11. Nalchadzhyan, A. (2007). Agressivnost' cheloveka [Human aggressiveness]. St. Petersburg : Piter. [in Russian].

12. Pavelkiv, V. R. (2004). Problemy ahresiyi v zarubizhniy literature [Problems of aggression in foreign literature]. Aktual'ni problemy psykholohiyi - Current problems of psychology. Kyiv : Milenium. 12 : 115-118. [in Ukrainian].

13. Rumyantseva, T.G. (1999). Faktory, sposobstvuyushchiye agressii. Psikhologiya chelovecheskoy agressivnosti [Factors contributing to aggression. Psychology of Human Aggression]. Minsk : Karvest. 64-115. [in Russian].

14. Freyd, Z. (2019). YA i Ono [Ego and Id]. Moscow : Eksmo. [in Russian].

15. Furmanov, I. A. (2007). Agressiya i nasiliye: diagnostika, profilaktika i korrektsiya [Aggression and violence: diagnosis, prevention and correction]. St. Petersburg : Rech'. [in Russian].

16. Shevchenko, N.F. \& Tsinyk, YA. (2021). Empirychne doslidzhennya proyaviv ahresyvnosti u ditey starshoho doshkil'noho viku [Empirical research of manifestations of aggression in senior preschool children]. The XIII International Science Conference "Development of modern science: theory, methodology, practice», March 18-19, 2021, Madrid, Spain. Madrid : International Science Group, 201-204. [in Ukrainian].

17. Cabello, R., Gutiérrez-Cobo, M. J., \& Fernández-Berrocal, P. (2017). Parental Education and Aggressive Behavior in Children: A Moderated-Mediation Model for Inhibitory Control and Gender. Frontiers in psychology, 8, 1181. https://doi.org/10.3389/fpsyg.2017.01181

18. Mitrofan, O., Paul, M., Weich, S. et al. (2014). Aggression in children with behavioural/emotional difficulties: seeing aggression on television and video games. BMC Psychiatry. 14, 287. https:// doi.org/10.1186/s12888-014-0287-7

19. Orpinas P., Frankovski R. (2001). The Aggression Scale : A Self-Report Measure of Aggressive Behavior for Young Adolescents. Journal of Rarly Adolescents. 21 (1). 50 - 67.

20. Suurland, J., van der Heijden, K. B., Huijbregts, S. C. J., Smaling, H. J. A., de Sonneville, L. M. J., Van Goozen, S. H. M., et al. (2016). Parental perceptions of aggressive behavior in preschoolers: inhibitory control moderates the association with negative emotionality. Child Dev. 87, 256-269. https:// doi.org/10.1111/cdev. 12455 